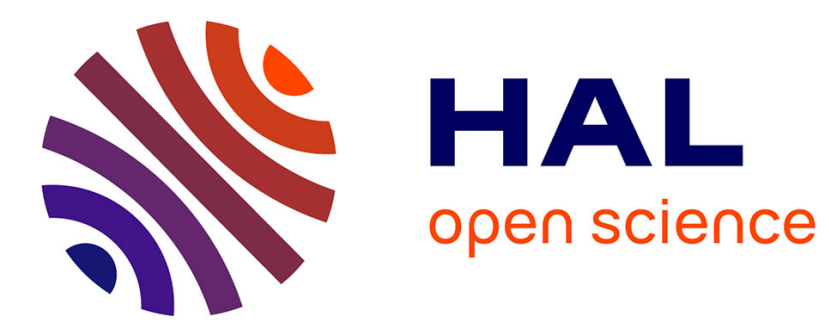

\title{
Tropical shift in decomposers' relative contribution to leaf litter breakdown in two Guinean streams
}

\author{
Nathalie Sia Doumbou Tenkiano, Eric Chauvet
}

\section{To cite this version:}

Nathalie Sia Doumbou Tenkiano, Eric Chauvet. Tropical shift in decomposers' relative contribution to leaf litter breakdown in two Guinean streams. Biotropica, 2017, 49 (4), pp.439-442. 10.1111/btp.12451 . hal-01626114

\section{HAL Id: hal-01626114 \\ https://hal.science/hal-01626114}

Submitted on 31 Oct 2017

HAL is a multi-disciplinary open access archive for the deposit and dissemination of scientific research documents, whether they are published or not. The documents may come from teaching and research institutions in France or abroad, or from public or private research centers.
L'archive ouverte pluridisciplinaire HAL, est destinée au dépôt et à la diffusion de documents scientifiques de niveau recherche, publiés ou non, émanant des établissements d'enseignement et de recherche français ou étrangers, des laboratoires publics ou privés. 


\section{Open Archive TOULOUSE Archive Ouverte (OATAO)}

OATAO is an open access repository that collects the work of Toulouse researchers and makes it freely available over the web where possible.

This is an author-deposited version published in : http://oatao.univ-toulouse.fr/ Eprints ID : 18647

To link to this article : DOI: $\underline{10.1111 / b t p .12451}$

URL : http://dx.doi.org/10.1111/btp.12451

To cite this version : Sia Doumbou Tenkiano, Nathalie and Chauvet, Eric Tropical shift in decomposers' relative contribution to leaf litter breakdown in two Guinean streams. (2017) Biotropica, vol. 49 (n 4). pp. 439-442. ISSN 1744-7429

Any correspondence concerning this service should be sent to the repository administrator: staff-oatao@ listes-diff.inp-toulouse.fr 


\title{
Tropical shift in decomposers' relative contribution to leaf litter breakdown in two Guinean streams
}

\author{
Nathalie Sia Doumbou Tenkiano ${ }^{1,2}$, and Eric Chauvet ${ }^{2,3}$ \\ ${ }^{1}$ University Julius Nyerere of Kankan, BP 209 Kankan, Guinea \\ ${ }^{2}$ University of Toulouse, UPS, INPT, CNRS, EcoLab, 31062 Toulouse, France
}

\begin{abstract}
The hypothesis that leaf litter breakdown in Guinean streams is governed by microorganisms was confirmed, supporting the reported latitudinal shift in decomposers' contribution to this process. The large body size of dominant macroinvertebrate decomposers (shrimps) only partially compensated for their very low densities. In contrast with other tropical regions mostly dominated by insect larvae, the functional consequences of global warming on these stream ecosystems may be less severe due to the lower sensitivity of crustaceans to temperature increase.
\end{abstract}

Abstract in French is available with online material.

Key words: aquatic hyphomycete; decomposition; detritivorous macroinvertebrate; diversity; function; fungi; latitudinal pattern; shrimp.

LEAF LITTER BREAKDOWN IS A CRUCIAL PROCESS FOR HEADWATER STREAms (Wallace et al. 1997). Such ecosystems, at both high and low latitudes, receive large amounts of plant litter, i.e., mainly dead leaves, which are at the basis of the stream detrital food web. Litter breakdown and the dynamics and relative contribution of decomposer types in temperate streams are now very well documented, While increasing information on litter breakdown from tropical streams is available, the relative implication of microorganisms and invertebrates has received less attention (Gonçalves et al. 2007, Jinggut \& Yule 2015, and the inter-regional comparison in Boyero et al. 2015 are among exceptions). Microbial breakdown is assumed to be higher because of the higher temperatures, and possibly lower competition for the resource, prevailing in tropical streams (Irons et al. 1994). In contrast, the implication of leaf-shredding invertebrates in the tropics, due to their generally lower abundance and body size, particularly for insect larvae (but see Yule et al. 2009), is hypothesized to be weaker than that in temperate regions. Nevertheless it must be stressed that the contribution of tropical invertebrates may be underestimated due to the poor knowledge of their diet and local variability effects (Camacho et al. 2009). These latitudinal patterns tend to be well supported by the results of a global study (Boyero et al. 2011). However, like in other global studies, a limitation to generalization lies in the paucity of data from some tropical regions, with, e.g., in the latter study for Africa only one site (Kenya-in Eastern Africa) also well documented by other studies (Dobson et al. 2002, Masese et al. 2014). In the present study conducted on two litter species in two streams in Guinea, we evaluated whether the relative contribution of microbial and invertebrate decomposers conformed to these patterns, i.e., high microbial breakdown versus low invertebrate-driven breakdown in reference to their temperate counterparts. In addition to document the hypothesized discrepancy in decomposers' relative involvement across latitudes, our second objective was to evaluate the specific impact of global climatic changes on this ecosystem process. Because some tropical regions such as Western Africa are predicted to suffer severe warming during early and late $21 \mathrm{st}$ century (IPCC 2013) and leaf litter represents an important portion of the organic carbon stock, consequences on the fate of carbon may be substantial while different from those in temperate regions.

Our study was conducted in two headwater streams located in the vicinity of Macenta in Forested Guinea, a typically forested region at low-medium altitude in Southeastern Guinea (Western Africa) near the border with Liberia. Facély Mara and Noulava are first-order oligotrophic streams running under a diverse deciduous forest. Substratum consisted of sand, gravel and cobbles. Water temperature recorded over the leaf breakdown experiment was stable around $22^{\circ} \mathrm{C}$. Albizia rigia (DC.) J.F.Macbr. and Millettia zechiana Harms are two common tree species in the vicinity of both streams and in Western Africa. Both species exhibit rather similar leaf traits even though the former had slightly higher $\mathrm{N}$ content than the latter (C:N ratios of 11.6 and 9.8, respectively). Five $\mathrm{g}( \pm 0.05 \mathrm{~g})$ of freshly-fallen leaves from either species were enclosed in coarse $(\mathrm{CM}, 9 \mathrm{~mm})$ and fine mesh $(\mathrm{FM}$, $0.5 \mathrm{~mm}$ ) bags. A total of 96 leaf bags (2 leaf species $\times 2$ mesh sizes $\times 2$ streams $\times 3$ blocks $\times 4$ dates) were prepared and sets of 16 bags ( 2 leaf species $\times 2$ mesh sizes $\times 4$ dates) were exposed in each of three blocks along each stream on 11 June 2014. CM bags allowed access to both macroinvertebrate and microbial decomposers while FM bags restricted leaf decomposition to microorganisms. As shown by visual inspection, FM bags did not contain any invertebrates except on rare occasions where 


\begin{tabular}{|c|c|c|c|c|}
\hline Stream & Leaf species & $k_{\text {total }}($ per d) & $k_{\text {microbial }}($ per $\mathrm{d})$ & $k_{\text {invertebrate }}($ per $\mathrm{d})$ \\
\hline Facély Mara & Albizia rigia & $0.03478( \pm 0.00245)^{\mathrm{a}, \mathrm{b}}$ & $0.02080( \pm 0.00255)^{\mathrm{a}}$ & $0.00547( \pm 0.00104)^{\mathrm{b}}$ \\
\hline Facély Mara & Millettia zechiana & $0.07646( \pm 0.00358)^{\mathrm{c}}$ & $0.04938( \pm 0.00189)^{\mathrm{b}}$ & $0.00223( \pm 0.00090)^{\mathrm{a}}$ \\
\hline Noulava & Millettia zechiana & $0.06634( \pm 0.00400)^{\mathrm{b}, \mathrm{c}}$ & $0.05121( \pm 0.00255)^{\mathrm{b}}$ & $0.00181( \pm 0.00048)^{\mathrm{b}}$ \\
\hline
\end{tabular}

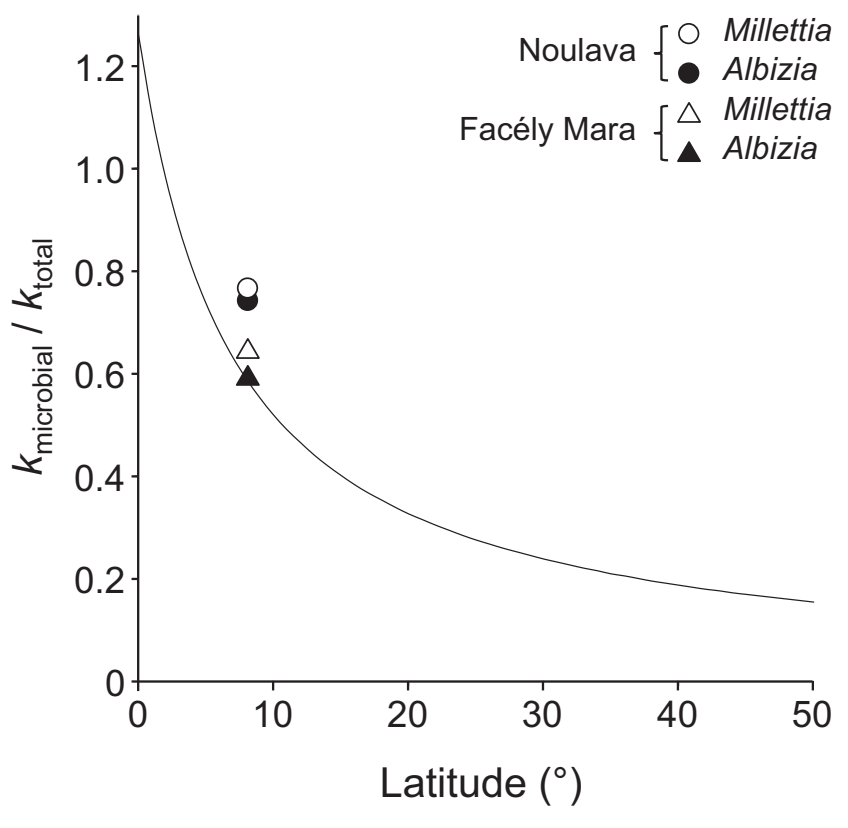

FIGURE 1. Ratio of microbial breakdown rate to total breakdown rate for two leaf litter species in two Guinean streams. The displayed relationship of this ratio against latitude $[y=8.83 /$ (latitude +6.97$)]$ is derived from two relationships determined in a global experiment and shown in Figs $2 \mathrm{c}$ and $\mathrm{f}$ in Boyero et al. (2011).

very few and tiny individuals occurred but did not, or only marginally, contribute to leaf breakdown. One leaf bag per leaf species, mesh size, block and stream was removed after 2, 4, 6 and 8 weeks. Biological and chemical determinations on retrieved litter material followed standard procedures (Graça et al. 2005, see Appendix S1). Breakdown rate, $k$, was determined according to the exponential model: $M_{\mathrm{t}}=M_{0} \cdot \mathrm{e}^{-k . \mathrm{t}}$, where $M_{\mathrm{t}}$ and $M_{0}$ are the remaining and initial ash free dry mass (AFDM) of leaves, respectively, and $\mathrm{t}$ the exposure time (in days), as derived from the decay model (Wieder \& Lang 1982).

Both leaf species decomposed fast with breakdown rates being slightly, but not significantly, higher in Facély Mara (Table $\left.1, k_{\text {total }}\right)$. In accordance with its very high $\mathrm{N}$ content (5.1\%), Millettia decomposed significantly faster than Albizia $([\mathrm{N}]=4.1 \%)$ in both types of leaf bags and in both streams. Leaf C:N ratios continuously increased with breakdown time, from
11.6 to 14.2 and 14.7 for Albizia in Facély Mara and Noulava, respectively, and from 9.8 to 15.6 and 17.6 for Milletia in Facély Mara and Noulava, respectively (Fig. S1). Such a C:N increase with breakdown time is an uncommon pattern being probably due to the conjunction of high initial $\mathrm{N}$ leaf content and low dissolved inorganic $\mathrm{N}$ content in the stream water.

The same discrepancy between leaf species occurred for microbial breakdown rates in both streams (Table 1). Importantly, microbial breakdown rates $\left(k_{\text {microbial }}\right)$ exceeded invertebrate-driven breakdown rates ( $\left.k_{\text {invertebrate }}\right)$ by about one order of magnitude, and this pattern was exacerbated in Millettia possibly resulting from its higher $\mathrm{N}$ content. Leaf-associated sporulation by aquatic hyphomycetes showed low maxima $(0.59$ and $0.63 / \mathrm{mg}$ leaf AFDM/d for Albizia in Facély Mara and Millettia in Noulava, respectively) and late increases compared to the early peaks occurring in temperate streams (Fig. S1). The community structure of aquatic hyphomycetes on decomposing leaves was dominated by few species, mostly known for their tropical distribution (Table S1). Such consistently low reproductive activity and diversity have been reported from tropical streams (Jabiol et al. 2013, Graça et al. 2016). In the present study, the low peaks of sporulation rate may have been due to the very low dissolved inorganic $\mathrm{N}$ and $\mathrm{P}$ contents in the water of our streams, as shown in manipulative experiments on nutrient effect (Suberkropp \& Chauvet 1995, Ferreira et al. 2006). It must, however, be underlined that the preeminence of fungal contribution to leaf breakdown is much more consistent across tropical regions than aquatic hyphomycete reproductive activity, with the latter being highly variable (e.g., discrepancies of two orders of magnitude between Mathuriau \& Chauvet 2002 and Ferreira et al. 2012). In contrast with temperate regions, sporulation rates in the tropics could thus not reflect fungal involvement in litter breakdown and be used as a reliable index of functional ecosystem impairment. The abundance of detritivore invertebrates peaked earlier than fungi but also at very low density (Fig. S1). The latter was, however, partially compensated for by the large individual body size and potentially substantial efficiency in leaf fragmentation as found in Caridina africana, a freshwater atyid shrimp that dominated detritivore assemblages (Table S1). The dominance of macroconsumer assemblages by shrimps is not uncommon in lowland streams of some regions, where they are shown to be efficient detritivores (e.g., Crowl et al. 2001). As a result, such lowland streams tend to differ much more from temperate streams than do high-altitude 
tropical streams (Boyero et al. 2009). Interestingly the difference of leaf mass in FM and CM bags, i.e., the mass loss due to macroinvertebrates, approximately equaled the consumption by C. africana as calculated from (i) individual density on Millettia at 2 weeks in Facely Mara and (ii) consumption rate determined for another species of Atyidae (Atyaephyra desmarestii, Callisto 2006), and (iii) a compensation factor for the between-taxa differences in per capita mass (McKie et al. 2008). Such a rough extrapolation must be used with caution as the contribution to leaf fragmentation may vary greatly among species of Atyidae (e.g., Atyia lanipes and A. desmarestii in Crowl et al. 2001 and Callisto 2006, respectively). Nevertheless, this illustrates the potential implication of such freshwater shrimps in leaf litter breakdown, in particular when they dominate detritivore assemblages, even though they only contribute to a minor portion of total leaf mass loss in the present study.

Overall, the poor invertebrate diversity and their very low contribution to leaf breakdown relative to microorganisms, when compared to their temperate counterparts, were in accordance to reported global patterns (e.g., Boyero et al. 2011) and even seemed to be exacerbated in our streams as reflected by very high $k_{\text {microbial }} / k_{\text {total }}$ ratios (Fig. 1 ), possibly due to the high litter content in $\mathrm{N}$. As anticipated in previous studies (Boyero et al. 2011, 2012), the loss of species and climate warming may have serious implications on the trophic structure and the whole ecosystem functioning of such streams. The contribution of cool-adapted detritivore taxa that may be close to their thermal maxima in the tropics (and thus particularly vulnerable to climate warming) has been suggested to be further reduced, and the conversion of organic compounds into $\mathrm{CO}_{2}$ through microbial breakdown to be stimulated leading to overall faster turn-over of organic C (Boyero et al. 2011). In the present streams of western Africa, such implications should nevertheless be tempered as the sensitivity of crustaceans to higher temperature as shown in Caridina (Hart 1983, de Silva 1989) may be lower than that of insect larvae many of which are cool-adapted. Whether Caridina africana is eurytherm remains unknown to our knowledge while the upper thermal tolerance appears somewhat inconsistent across Caridina species (Hart 1983, de Silva 1989), thus requiring complementary studies but still making our assumption plausible. Whereas the predominance of micro- versus macro-decomposers is confirmed by the present study, the impact of future temperature increase may be less severe than in other tropical streams, stressing that regional particularities preclude any generalization about the consequences of global warming on the functioning of tropical stream ecosystems.

\section{ACKNOWLEDGMENTS}

We are grateful to the French Embassy in Republic of Guinea, which provided travel funds to NT and EC. The staff of the "Centre de Recherches Agronomiques de Sérédou" is acknowledged for facilitating the access to field sites and technical rooms of the centre. We thank Frédéric Julien and Sylvain Lamothe for their contribution to chemical analyses and biological identifications, respectively.

\section{SUPPORTING INFORMATION}

Additional Supporting Information may be found online in the supporting information tab for this article:

APPENDIX S1. Characteristics of study sites-Experimental and analytical procedures.

FIGURE S1. Carbon-to-Nitrogen ratio of two leaf species decomposing in two Guinean streams, and litter-associated fungal sporulation rate and number of macroinvertebrate individuals.

TABLE S1. Aquatic byphomycete and macroinvertebrate taxa associated with two litter species decomposing in two Guinean streams.

\section{LITERATURE CITED}

Boyero, L., A. Ramírez, D. Dudgeon, and R. G. Pearson. 2009. Are tropical streams really different? J. North Am. Benthol. Soc. 28: 397403.

Boyero, L. , R. G. Pearson, M. O. Gessner, L. A. Barmuta, V. Ferreira, M. A. S. Graça, D. Dudgeon, A. J. Boulton, M. Callisto, E. Chauvet, J. E. Helson, A. Bruder, R. J. Albariño, C. M. Yule, M. Arunachalam, J. N. Davies, R. Figueroa, A. S. Flecker, A. Ramírez, R. G. Death, T. Iwata, J. M. Mathooko, C. Mathuriau, J. F. Gonçalves Jr, M. S. Moretti, T. Jinggut, S. Lamothe, C. M’Erimba, L. Ratnarajah, M. H. Schindler, J. Castela, L. M. Buria, A. Cornejo, V. D. Villanueva, And D. C. West. 2011. A global experiment suggests climate warming will not accelerate litter decomposition in streams but might reduce carbon sequestration. Ecol. Lett. 14: 289-294.

Boyero, L., R. G. Pearson, D. Dudgeon, V. Ferreira, M. A. S. Graça, M. O. Gessner, A. J. Boulton, E. Chauvet, C. M. Yule, R. J. Albariño, A. Ramírez, J. E. Helson, M. Callisto, M. Arunachalam, J. Chará, R. Figueroa, J. M. Mathooko, J. F. Gonçalves Jr, M. S. Moretti, A. M. Chará-Serna, J. N. Davies, A. Encalada, S. Lamothe, L. M. Buria, J. Castela, A. Cornejo, A. O. Y. Li, C. M’Erimba, V.D. Villanueva, M. C. Zúñiga, C. M. Swan, and L. A. Barmuta. 2012. Global patterns of distribution in stream detritivores: implications for biodiversity loss in changing climates. Glob. Ecol. Biogeogr. 21: 134-141.

Boyero, L., R. G. Pearson, M. O. Gessner, D. Dudgeon, A. Ramírez, C. M. Yule, M. Callisto, C. M. Pringle, A. C. Encalada, M. Arunachalam, J. Mathooko, J. E. Helson, J. Rincón, A. Cornejo, A. S. Flecker, C. Mathuriau, C. M. Erimba, J. F. Gonçalves Jr, M. MorETTI, AND T JiNGGUT. 2015. Leaf-litter breakdown in tropical streams: is variability the norm? Freshw. Sci. 15: 759-769.

Callisto, M. 2006. Some laboratory evidences about the Mediterranean shrimp Atyaephyra desmarestii feeding on Alnus glutinosa (L.) Gaertn. leaf detritus. Acta Limnol. Bras. 18: 225-228.

Camacho, R., L. Boyero, A. Cornejo, A. Ibáñez, and R. G. Pearson. 2009. Local variation in shredder distribution can explain their oversight in tropical streams. Biotropica 41: 625-632.

Crowl, T. A., W. H. McDowell, A. P. Covich, And S. L. Johnson. 2001. Freshwater shrimp effects on detrital processing and nutrients in a tropical headwater stream. Ecology 82: 775-783.

Dobson, M., A. Magana, J. Mathooko, and F. Ndewga. 2002. Detritivores in Kenyan highland streams: more evidence for the paucity of shredders in the tropics? Freshw. Biol. 47: 909-919.

Ferreira, V., A. C. Encalada, and M. A. Graça. 2012. Effects of litter diversity on decomposition and biological colonization of submerged litter in temperate and tropical streams. Freshw. Sci. 31: 945-962. 
Ferreira, V., V. Gulis, And M. A. S. Grach. 2006. Whole-stream nitrate addition affects litter decomposition and associated fungi but not invertebrates. Oecologia 149: 718-729.

Gonçalves, J. F., M. A. GraçA, And M. Caldisto. 2007. Litter decomposition in a Cerrado savannah stream is retarded by leaf toughness, low dissolved nutrients and a low density of shredders. Freshw. Biol. 52: 1440-1451.

Graça, M. A. S., F. BÄrlocher, And M. O. Gessner. 2005. Methods to study litter decomposition. A practical guide. Springer, Dordrecht, the Netherlands.

Graç., M. A. S., K. Hyde, and E. Chauvet. 2016. Aquatic hyphomycetes and litter decomposition in tropical - subtropical low order streams. Fungal Ecol. 19: 182-189.

Hart, R. C. 1983. Temperature tolerance and southern African distribution of a tropical freshwater shrimp Caridina nilotica (Decapoda: Atyidae). S. Afr. J. Zool. 18: 67-70.

IPCC. 2013. Climate Change 2013: The Physical Science Basis. Contribution of the Intergovernmental Panel on Climate Change Working Group I to The Fifth Assessment Report.

Irons, J. G., M. Oswood, R. Stout, And C. Pringle. 1994. Latitudinal patterns in leaf litter breakdown: is temperature really important? Freshw. Biol. 32: 401-411.

Jabiol, J., A. Bruder, M. O. Gessner, M. Makkonen, B. G. McKie, E. T. H. M. Peeters, V. C. Vos, and E. Chauvet. 2013. Diversity patterns of leaf-associated aquatic hyphomycetes along a broad latitudinal gradient. Fungal Ecol. 6: 439-448.

JingGut, T., AND C. M. Yule. 2015. Leaf-litter breakdown in streams of East Malaysia (Borneo) along an altitudinal gradient: initial nitrogen content of litter limits shredder feeding. Freshw. Sci. 34: 691-701.
Masese, F. O., N. Kitaka, J. Kipkemboi, G. M. Gettel, K. Irvine, and M. E. Mcclain. 2014. Macroinvertebrate functional feeding groups in Kenyan highland streams: evidence for a diverse shredder guild. Freshw. Sci. 33: 435-450.

Mathuriau, C., And E. Chauvet. 2002. Breakdown of leaf litter in a neotropical stream. J. North Am. Benthol. Soc. 21: 384-396.

McKie, B. G., G. Woodward, S. Hladyz, M. Nistorescu, E. Preda, C. Popescu, P. S. Giller, and B. Malmqvist. 2008. Ecosystem functioning in stream assemblages from different regions: contrasting responses to variation in detritivore richness, evenness and density. J. Anim. Ecol. 77: 495-504.

de SILVA, K. 1989. Temperature tolerances and geographic distribution of three species of Caridina (Decapoda, Atyidae) in Sri Lanka. Int. Rev. Hydrobiol. 74: 95-107.

Suberkropp, K., and E. Chauvet. 1995. Regulation of leaf breakdown by fungi in streams : influences of water chemistry. Ecology 76: 14331445.

Wallace, J. B., S. L. Eggert, J. L. Meyer, and J. R. Webster. 1997. Multiple trophic levels of a forest stream linked to terrestrial litter inputs. Science (80-.) 277: 102-104.

Wieder, R. K., AND G. E. Lang. 1982. A critique of the analytical methods used in examining decomposition data obtained from litter bags. Ecology 63: 1636-1642.

Yule, C., M. Y. Leong, K. C. Liew, L. Ratnarajah, K. Schmidt, H. M. Wong, R. G. Pearson, and L. Boyero. 2009. Shredders in Malaysia: abundance and richness are higher in cool upland tropical streams. J. North Am. Benthol. Soc. 28: 404-415. 